\title{
A Trilingual Glossary of Kasiguranin Terms on Person's Anatomy and Body Functions
}

\author{
Celso P. Resueño, Jr. \\ College of Education, Nueva Ecija University of Science and Technology, Cabanatuan City, Nueva Ecija, Philippines.
}

\begin{abstract}
How to cite this paper: Celso P. Resueño, Jr. (2020). A Trilingual Glossary of Kasiguranin Terms on Person's Anatomy and Body Functions. The Educational Review, USA, 4(12), 225-232.

DOI: $10.26855 /$ er.2020.12.003
\end{abstract}

Received: November 2, 2020

Accepted: November 30, 2020

Published: December 23, 2020

Corresponding author: Celso P. Resueño, Jr., College of Education, Nueva Ecija University of Science and Technology, Cabanatuan City, Nueva Ecija, Philippines.

Email: rcelso72@yahoo.com

\begin{abstract}
This linguistic ethnographic type of research generally aims to produce a trilingual (Kasiguranin-Filipino-English) glossary terms on person's anatomy and body functions. It also includes terms associated with person's ailments and injuries, gender, and life stages. Further, it intends to identify, describe, and differentiate the linguistic features of the Kasiguranin words with Filipino language in terms of their phonological and morphological functions. Immersion, field notes, structured, and conversational interviews were used in collecting word identities. The trilingual glossary underwent lexicographic and translation processes such as preparation, data collection, and analyses of lexical entries. Findings revealed that there were 135 distinct Kasiguranin terms in terms of person's anatomy and body functions. Further, Kasiguranin language (KL) shows the same phoneme and combinations with Filipino language (FL) except for the absence of $/ \mathrm{f} / \mathrm{g} / \mathrm{v} /$, and /z/ sounds. Moreover, it reveals that /1/ low, /2/ normal, and /3/ high is the pitch level followed by the speakers when converse. Also, KL uses full and/or suspension contours in contrast with FL which uses rising final contour. In terms of morphological aspect, it was found out that KL has alternants for the imperative form while FL has no counterparts. Kasiguranin language uses MAG-E and being proceeded by a noun. Moreover, KL uses the alternant MAKA- for the expression of something they feel, i.e. MAKA- and being proceeded by an adjective, while FL uses NAKAKA-.
\end{abstract}

\section{Keywords}

Kasiguranin, Trilingual Glossary, Translation, Phonological And Morphological, Aspects, Immersion

\section{Introduction}

Department of Education Order No. 16, s. 2012, also known as the "Guidelines on the Implementation of the Mother Tongue-Based-Multilingual Education (MTB-MLE)”, mandated all public schools, specifically Kindergarten, Grades 1, 2 and 3, to implement the use of mother tongue as part of the K to 12 Basic Education Program. This program supports the goal of "Every Child-A-Reader and A-Writer by Grade 1". Pupils at these stages are exposed and taught the basic academic, social, and developmental needs. One of the basic developmental skills among pupils, at this stage, is the different parts of human body (kindergarten-lessons.com, 2019). Unfortunately, there were some schools which cannot and do not afford to use of MTB-MLE because of either lack of learning materials or teacher's lack of basic knowledge on the target language (Eslit, 2017). There was indeed an adversity on teaching materials when it comes to the implementation of MTB-MLE.

On the other hand, the province of Aurora, in the eastern part of Luzon, has a multiplicity in phonological and lexical 
disparities among the municipalities as evident in some lexical variations among speakers. Kasiguranin language is one of the variations. Aside from their distinct accent, people outside the municipality could not decipher nor understand the language (Resueno, 2015). Only people from Casiguran understand their language. The worse is, the said language is considered "endangered" (Ethic Groups Philippines, 2011). Hence, documenting and preserving the language are indispensable concerns which need to immediately address.

On the other side, someone who tries to be familiarized with a second or foreign language tries to examine its linguistic features. Each human language is a multifarious of information and abilities enabling speakers of the language to communicate with each other, to express ideas, hypotheses, emotions, desires, and all the other things that need expressing. Linguistics is the study of these knowledge systems in all their aspects: how is such a knowledge system structured, how is it acquired, how is it used in the production and comprehension of messages, and how does it change over time.

Considering all these, the researcher attempted to preserve, describe and provide a trilingual glossary of terms on person's anatomy and body functions. It also included terms associated with person's ailments and injuries, gender and life stages. Further, it intended to identify, describe and differentiate the linguistic features of the Kasiguranin words with Filipino language in terms of their phonological and morphological functions.

\section{Statement of the Problem}

This study attempted to preserve, describe and provide a trilingual glossary of Kasiguran terms in relation to person's anatomy, body functions, ailments and injuries and life.

Specifically, it tried to describe the following:

1. Classification of Kasiguranin terms of person's:

1.1. anatomy;

1.2. body functions;

1.3. ailments and injuries; and

1.4. life

\subsection{1. gender; and}

1.4.2. stages.

2. Linguistic features of Kasiguranin words in terms of the following:

2.1. phonological aspect; and

2.2. morphological aspect.

\section{Methodology}

The study employed a linguistic ethnographic type of research. Immersion, field notes, survey questionnaire, conversational and structured interviews were utilized among 30 adolescents, 30 young adults, 30 adults and 32 senior respondents who were all residents and natives of Casiguran, Aurora - a second class town situated in the northern part of the province. It is located 121 kilometers $(75 \mathrm{mi}$ ) north-east from Baler, the provincial capital (casiguran-aurora.gov.ph/, 2020).

The study employed the first three phases of a research design from Rozul (2004) namely preparation, data collection, and analyses of lexical entries.

\section{Results and Discussions}

\subsection{Classification of Kasiguranin terms}

The following tables present the distinct Kasiguranin words which are pertaining to person's anatomy, body functions, ailments and injuries, gender and life stages.

\subsubsection{Anatomy}

Table 1 shows the trilingual glossary of distinct Kasiguranin words pertaining to person's anatomy.

Table 1. Person's Anatomy

\begin{tabular}{ccc}
\hline Kasiguranin & English & Filipino/Tagalog \\
\hline ab’bot ng bul’le & anus & butas ng puwit \\
Abagá & abagá & abagá \\
\hline
\end{tabular}




\begin{tabular}{|c|c|c|}
\hline ad'deg & back & likod \\
\hline ad'dong & nose & ilong \\
\hline al'leg & neck & leeg \\
\hline bag'gí & body & katawan \\
\hline beng-beng & ear & tenga \\
\hline buk'kel & buk'kel & buk'kel \\
\hline bul'le & buttocks & pigi; puwit \\
\hline Bulong & heel & sakong \\
\hline Bungaw & testes & bayag \\
\hline but'to & penis & titi \\
\hline daring-daring & Adam's apple & gulung-gulungan \\
\hline das'set & feet & paa \\
\hline Digí & blood & dugo \\
\hline guram'mat & finger & daliri \\
\hline Guramot & toenail & kukosadalirisapaa \\
\hline kamannadadak’kel & big toe & hinlalaki \\
\hline karubukob; bukraw & throat & lalamunan \\
\hline kid’dap & eyelashes & pilikmata \\
\hline Kiray & eyebrow & kilay \\
\hline Kongkong & coccyx & kuyukot \\
\hline Kulet & skin & balat \\
\hline lap’pe & thigh & hita \\
\hline lasen; labey & muscle & laman; kalamnan \\
\hline Lima & hand & kamay \\
\hline mud'ding & forehead & noo \\
\hline Ngaras & gums & gilagid \\
\hline ngip’pen & tooth & ngipin \\
\hline Padingel & cheek & pisngi \\
\hline pus-ún & abdomen & puson \\
\hline Rakaw & chest & dibdib \\
\hline raw’wed & calf & kalamnan ng binti \\
\hline Rupá & face & muka \\
\hline sap’peng & waist & baywang \\
\hline sik’kó & elbow & siko \\
\hline sup’pang & hip & balakang \\
\hline tak'geng & ribs & tadyang \\
\hline Timed & chin & baba \\
\hline Tuldú & index finger & hintuturo \\
\hline Uték & brain & utak \\
\hline
\end{tabular}

Forty one (41) words are solicited pertaining to person's anatomy. All of these words are related to the branch of bi- 
ology concerned with the study of the structure of a person and his or her body parts. Moreover, these words also refer to the different organs and structures of the human body.

\subsubsection{Body Function}

Table 2 shows the trilingual glossary of distinct Kasiguranin words pertaining to person's body function.

Table 2. Body Function

\begin{tabular}{|c|c|c|}
\hline Kasiguranin & English & Filipino/Tagalog \\
\hline am'mo & kiss & halik \\
\hline ang’nges & breathe & hinga \\
\hline ar'rob & smell & amoy \\
\hline bi-am & smack & damping halik \\
\hline Buntal & punch & suntok \\
\hline Deldel & lick & dumila \\
\hline Dusak & stub & saksak \\
\hline gimud-gimud; anasat & mutter & pagbulung-bulong \\
\hline Gusgus & scratch & kamot \\
\hline ikib’bet & shrug & ikibit \\
\hline il'leng & stare & tingin \\
\hline Ileng & glance & sulyap \\
\hline ital'len & swallow & lunok \\
\hline itendak; karsag & kick & sipa \\
\hline kagat'ten; kat’teb & bite & kagat \\
\hline Kagi & talk & magsalita \\
\hline kis’sep & blink & kurap \\
\hline Kuman & eat & kain \\
\hline mag'guwab & yawn & hikab; maghikab \\
\hline Magkagí & speak & magsalita \\
\hline ngatngat'ten & chew & nguya \\
\hline Pangkenam & taste & panlasa \\
\hline Sangrot & sniff & singhot \\
\hline sapuk'ken; sampil’long & slap & sampal \\
\hline Tuldó & point & tumuro \\
\hline tumag'gem & excrete & maglabas ng dumi \\
\hline Umanges & eructate & dumighay \\
\hline umesbú; mag-esbú & urinate & umihi \\
\hline Yegyeg & shake & iling; alog; umuga \\
\hline
\end{tabular}

There are twenty nine (29) distinct words which are listed under person's body functions. These terms denote the mechanisms that work to keep the human body alive and functioning through scientific enquiry into the nature of mechanical, physical and biochemical functions of humans, their organs and the cells of which they are composed. Furthermore, these words also refer to the study of functions and are closely related to anatomy which is the study of form.

\subsubsection{Ailments and Injuries}

Table 3 shows the trilingual glossary of distinct Kasiguranin words pertaining to person's ailments and injuries. 
Table 3. Ailments and Injuries

\begin{tabular}{|c|c|c|}
\hline Kasiguranin & English & Filipino/Tagalog \\
\hline bad’dit & dwarfism & pagkapandak \\
\hline Binulos & diarrhea & dayariya \\
\hline Buktet & pregnant & buntis \\
\hline Bulutung & chickenpox & bulutong \\
\hline Butalé & boil & pigsa \\
\hline Dalinga & athlete's foot & alipunga \\
\hline Gusok & ulcer & ulser \\
\hline hindimagenak & infertility & pagkabaog \\
\hline hindimakatid’du & insomnia & hindipagkatulog \\
\hline hindimaturaw & dyspepsia & hindipagkatunaw \\
\hline ik’ker & phlegm & plema \\
\hline ik’kur & coughs & ubo \\
\hline kat’tal & allergies & alergi \\
\hline kat'teb & bite & kagat \\
\hline kat'tel & itch & kati \\
\hline kus’seng & bruises & gasgas \\
\hline lad’du & fever & lagnat \\
\hline Lasá & bland & walangpanlasa \\
\hline legrá; dig'gi & menstruation & regla \\
\hline loyong (bungaw) & hernia & luslos \\
\hline luku-luk’ku & mental disorder & sakitsapag-iisip \\
\hline mabal’lay & lethargic & matamlay; antukin \\
\hline Mabawá & bad breath & mabahonghininga \\
\hline Madegnen & chilly & giniginaw \\
\hline magal’lap & hungry & gutom \\
\hline magot'ta & nausea & pagkasuka \\
\hline Magsipon & runny rose & inuuhog \\
\hline magtig'gus & stomachache & sakit ng tiyan \\
\hline Malikbúg & blurry & Malabo \\
\hline Malinog & dizziness & pagkahilo \\
\hline Manteng & fear & takot \\
\hline map’pet & bitter & mapait \\
\hline masaket ang bukraw & sore throat & masakit ang lalamunan \\
\hline mataas ang dig’gi & hypertension & altapresyon \\
\hline matam-is & sweet & matamis; malambing \\
\hline matongtong; ab’bot ng ngip’pen & cavities & butassaipin \\
\hline nabur'rak & blindness & pagkabulag \\
\hline Pagel & tired & pagod \\
\hline
\end{tabular}




$\begin{array}{ccc}\text { Paktá } & \text { freckles } & \text { pekas } \\ \text { pang'ged } & \text { pimple } & \text { tagihawat } \\ \text { pangang'gu } & \text { nosebleed } & \text { balinguyngoy } \\ \text { par'rek } & \text { hoarseness } & \text { pagkapaos } \\ \text { pas'sa } & \text { black eye } & \text { pasasamata } \\ \text { pas'se } & \text { burns } & \text { paso } \\ \text { Pokpok } & \text { hair loss } & \text { pagkakalbo } \\ \text { Puseng } & \text { broken } & \text { bali } \\ \text { sak'ketsapus'so } & \text { heart disease } & \text { sakitsapuso } \\ \text { sak'ketsaul'lo } & \text { headache } & \text { sakit ng ulo } \\ \text { saketsabag'gi } & \text { muscle pain } & \text { sakitsakalamnan } \\ \text { saket; maapdus } & \text { painful } & \text { masakit } \\ \text { tab’bul } & \text { constipation } & \text { tibi } \\ \text { Talengo } & \text { cut } & \text { hiwa; hiwain } \\ \text { Talingo } & \text { wound } & \text { sugat } \\ \text { tul'lang } & \text { deafness } & \text { pagkabingi } \\ \text { Uwaw } & \text { thirsty } & \text { uhaw }\end{array}$

There are fifty-six (56) words which are listed under person's ailments and injuries. These are the distinct Kasiguranin terms used when they refer to particular abnormals, pathological conditions that affect part or all of a human body. They are also often construed as a medical condition associated with specific symptoms and signs. They may be caused by factors originally from an external source such as infectious disease or it may be caused by internal dysfunctions such as autoimmune diseases. Moreover, these words are used broadly to refer to any condition that causes pain, dysfunction, distress, social problems or death to the person afflicted or similar problems for those in contact with the person. These terms also sometimes include disabilities, disorders, syndromes, infections, isolated symptoms, deviant behaviors and atypical variations of structure and functions while in other contexts and for other purposes, these may be considered distinguishable categories. Ailments usually affect people not only physically, but also emotionally, as contracting and living with a disease can alter one's perspective on life and one’s personality.

\subsubsection{Gender}

Table 4 shows the trilingual glossary of distinct Kasiguranin words pertaining to person's gender.

Table 4. Gender

\begin{tabular}{ccc}
\hline Kasiguranin & English & Filipino/Tagalog \\
\hline bab'bi & girl & babae \\
lalak'ke & boy & lalaki \\
\hline
\end{tabular}

Generally, there are only two (2) words which belong to person's gender. These words refer to the range of characteristics pertaining to, and differentiating between, masculinity and femininity. Depending on the context, these characteristics may include biological sex (i.e. the state of being male, female or intersex), sex-based social structures (including gender roles and other social roles), or gender identity.

\subsubsection{Stages}

Table 5 shows the trilingual glossary of distinct Kasiguranin words pertaining to person's life stages.

Table 5. Stages

\begin{tabular}{ccc}
\hline Kasiguranin & English & Filipino/Tagalog \\
\hline Anak & chid & bata \\
bak'kes; lakay & adult & matanda \\
\hline
\end{tabular}




$\begin{array}{ccc}\text { Binistok } & \text { adolescence } & \text { pagbibinata; pagdadalaga } \\ \text { Sanggul } & \text { infant } & \text { sanggol }\end{array}$

There are only four (4) words which are listed under the person's life stages. These terms generally pertain to a single step or degree in a process; a particular phase, period, position, etc., in a process, development, or series of a person.

\subsection{Linguistic features of Kasiguranin terms}

The following discussions expound linguistic features of the distinct Kasiguranin terms in terms of their phonological and morphological aspects.

\subsubsection{Phonological aspect}

The Kasiguranin Language (KL) shows the same segmental phonemes and combinations with Filipino Language (FL), as follows:

5 vowels / a, e, i, o, u /

7 diphthongs / aw, ay, ey, iw, iy, oy, uy /

15 consonants

stops / b, d, k, g, p, t /

nasals / $\mathrm{m}, \mathrm{n}, \mathrm{ng} /$

fricatives / h, s /

lateral / 1 /

$\operatorname{tap} / \mathrm{r} /$

glides / w, y /

Kasiguranin language does not have the sound of $/ \mathrm{f} /, \mathrm{j} /$, and $/ \mathrm{z} /$.

The KL has the following suprasegmentals: pitch levels: /1/ low; /2/ normal; /3/ high

The FL has pitch levels of /3/ high; /2/ normal; /1/ low

Kasiguranin word stress or accent is normally predictable on the terminal syllable of a word and uses high pitch level on the terminal syllables of the words, which makes it different from Filipino language which uses low pitch level on the terminal syllables, as shown by a number of minimal pairs, such as:

$\begin{array}{ll}\text { KL } & \text { FL } \\ \text { /abusado (3)/ } & \text { /abusado (1)/ } \\ \text { /buhaya (3)/ } & \text { /buwaya (1)/ } \\ \text { /dambana (3)/ } & \text { /dambana (1)/ } \\ \text { /rayuma (3)/ } & \text { /rayuma (1)/ } \\ \text { /bota (3)/ } & \text { /bota (1)/ }\end{array}$

Kasiguranin words containing closed penultimate syllables are variably accented on the ultimate or the penultima, without any corresponding change in meaning: /abusadó/-/abusádo/ "abusive”; /buhayá//buwáya/ "alligator”; /dambaná/-/dambána/ "altar”; /rayumá/-/rayúma/ “arthritis”; /botá/-/bóta/ "boots.”

The basic phonological difference between Kasiguranin Language and Filipino Language chiefly concern intonation contours, having a melodic glide within the syllables, especially in the word-terminal syllables. There is a greater incidence of jumping to a higher pitch level at the last syllable, as shown on the presented examples.

Moreover, Kasiguranin language tends to change the sound of /i/ to /e/ such as "sakit" to "saket"; "asin" to "asen"; "kanin" to "kanen”; "matindi” to "matende"; "isa” to "es-sa”; "minsan" to "mensan"; "lalaki” to "lalake-ke”; "ngipin" to "ngip-pen”; "masungit” to "masunget”; "iling” to "il-leng”; "anim” to "an-nem”; "mapili" to "mapile”; "bukid” to "buk-ked."

Likewise, the Kasiguranin language tends to change the sound of /o/ to /u/ such as "luto" to "lutu"; "dito" to "ditu"; "iyo" to "iyu”; "puson" to "pus-un"; "tambo" to "tambu”; "sulo" to "sulu”; "abo" to "ab-bu”; "mundo" to "mundu”; "kugon" to "kugun”; "hambog” to "hambug”; "pito" to "pitu”; "bilog” to "bilug”; "lamog” to "lamug”; "nakayayamot” to "makayamut"; "gamot" to "gamut"; "talong” to "talung."

In yes-or-no questions, Kasiguranin language uses full fall and/or sustension contours, in contrast with Filipino language which uses rising final contour.

terminal contours: / $\downarrow /$ full fall; / / partial fall; / / rising; and $/ \rightarrow /$ sustention.

FL $/ \uparrow$ Kumain $\downarrow$ ka na $\uparrow /$

KL /-Kinuman ka na-/

Without the question marker, Filipino language has a rising final contour while Kasiguranin language follows the sustention contour. 


\subsubsection{Morphological Aspect}

Difference between FL and KL case markers occurs only in the personal plural forms. While FL has sina, nina, and kina, KL has only kade for the three given words.

FL KS Gloss

sina Sam kade Sam "Sam and others"

nina Sam kade Sam 'of, by Sam and others"

kina Sam kade Sam 'to, for Sam and others"

Also, the use of "atam" for "naten."

Kasiguranin language "ditu” 'dito (this)' refers to nouns near the speaker and the addressee, while "dun” 'doon (that)' refers to the nouns far from the speaker and the addressee.

In addition, KL has alternants for the imperative form while FL has no counterparts. Kasiguranin language uses MAG-E and being proceeded by a noun.

KL

mag-e-toyo

mag-e-papel

mag-e-bulaklak
FL

kumuha ng toyo

kumuha ng papel

kumuha ng bulaklak

Moreover, KL uses the alternant MAKA- for the expression of something they feel, i.e. MAKA- and being proceeded by an adjective, while FL uses NAKAKA-

KL

maka-anteng

maka- parabut-te

maka-rebsa

maka-sanike

maka-sida
FL

nakakatakot

nakakapangilabot

nakakadiri

nakakahiya

nakakasira

\section{References}

Casiguran-aurora.gov.ph. (2020). Municipality Profile. Retrieved from http://www.casiguran-aurora.gov.ph/.

Department of Education. (2020). Guidelines on the Implementation of the Mother Tongue-Based-Multilingual Education (MTB-MLE). Retrieved from https:/www.deped.gov.ph/2012/02/17/do-16-s-2012-guidelines-on-the -implementation-of-the-mother-tongue-based-multilingual-education-mtb-mle/.

Eslit, E. R. (2017). Binisaya Instruction: Facing the MTB-MLE Challenges Head-on. https://www.researchgate. net/publication/321025673.

Education.com. (2020). Kindergarten Lesson Plans. Retrieved from https://www.education.com/lesson-plans/kindergarten/.

Resueno, C. P. (2015). A Lexicographic Study of Kasiguranin Language. Unpublished MA thesis. Nueva Ecija University of Science and Technology.

Rozul, R. H. (2004). Developing a Monolingual Dictionary of Obsolescent Tagalog Words in Tagaytay City, Amadeo and Indang Cavite. Unpublished PhD dissertation. De La Salle University. 